\title{
Learning Communication Strategy Based on Contextual Teaching and Learning to Increase Awareness of Student Learning in South Sulawesi
}

\author{
Jeanny Maria Fatimah ${ }^{1}$, Dwia Aries Tina Pulubuhu ${ }^{2}$, Arianto $^{3}$ \\ \{jeannyfatimah@gmail.com ${ }^{1}$,dwiatn@yahoo.com ${ }^{2}$, arianto@unhas.ac.id $\left.{ }^{3}\right\}$ \\ Department of Communication Science, Faculty Social and Political Science, Hasanuddin University. J1. \\ Perintis Kemerdekaan KM. 10. Makassar, Indonesia ${ }^{1,3}$ \\ Department of Sociology, Faculty Social and Political Science, Hasanuddin University. Jl. Perintis \\ Kemerdekaan KM. 10. Makassar, Indonesia ${ }^{2}$
}

\begin{abstract}
Contextual Teaching and Learning (CTL) based learning communication is a child's learning process that is implemented to help educators connect learning material and real world situations. The research problem is how learning communication strategies based on CTL in improving children's ability to apply learning outcomes in everyday life. This method is a constructivism learning system that builds one's own understanding actively, creatively and productively based on knowledge and learning experiences. The research method is interpretive through a case study approach. Research intensively focuses on one particular object that is studied as a case. The focus of the case study is the process of communicating the learning of teachers and students of the MDIA Potere Elementary School in Makassar City, located on the coast of Makassar City in South Sulawesi Province. This case study was collected from various direct sources in real life from the cases investigated. The results of the study found and categorized learning communication strategies based on CTL encouraging the creation of five forms of learning, namely: relating, experiencing, applying, applying, cooperating, and transferring knowledge. Learning communication strategies tend to increase student awareness in coastal areas showing a low tendency in terms of relating, applying, and cooperating.
\end{abstract}

Keywords: Contextual Teaching, Learning, Learning Awareness, Fisherman Children, South Sulawesi 


\section{Introduction}

In Indonesia the education sector of coastal fishermen children requires serious attention from the central and regional governments. Children of coastal fishermen should get the same opportunity to get access to education. The problem of coastal fishermen children still lags behind in seeking knowledge, among others, the lack of basic educational facilities and the limited insight into the importance of education. They help parents find a living to support their daily needs. In fact, the level of education of coastal communities is still relatively low. The average level of education of coastal communities stops at the elementary school level and some have education only at the junior high school level.

Learning strategies undertaken must be adjusted to the tendency of the level of intelligence possessed by students, so that the potential of students can develop. The learning approach or curriculum applied is not built based on the diversity of students' learning styles and the level of intelligence possessed by students, so that the potential for intelligence possessed by students becomes undeveloped. [1]

Learning systems to increase children's learning awareness that are applied so far are still using teacher-centered learning. As a result, students get bored quickly because of the monotonous learning process. For this reason, a learning approach is more emphasized or student-centered. This strategy changes the paradigm of student learning by optimizing the structure of the CTL approach so that students are able to fully understand the learning material provided by the teacher. Learning communication strategies based on CTL are holistic learning processes, processes that pay attention to the needs and potential of students.

In the coastal areas of the province of South Sulawesi, they generally take formal education which is spread along the coast. Formal schools serve as the main educational tool to get higher knowledge. For parents there is no other choice for children to help earn a living in meeting household needs. The impact, children do not have time to complete the learning tasks given by teachers from school. Parents pay less attention to the development of children's education in school. Children usually go out to sea to help parents make a living.

At the age of adolescence, fishermen began to sail and go to sea, so they rarely went to school. In fact, the biggest challenge is how to build the lives of fishermen families to improve their welfare. This achievement can be achieved through education. Increasing the educational ability of fishermen's children raises reading awareness and the dignity of life in relation to marine and coastal resources. Until now the low quality and relevance of coastal children's education is influenced by a number of factors, including the inability to create a process of learning awareness and quality children's learning [2]

Awareness of the learning of coastal fishermen children is urgent to ensure the fulfillment of the educational needs of every child. Children's learning communication strategies CTL that can help teachers connect material and real-world situations of students. The impact encourages students to practice the knowledge gained by life as family and community members in the coastal area. To strengthen the learning experience that is applicable for students, learning is needed that provides opportunities for students to do, try, and experience themselves (learning to do), and not only listeners who are passive but active recipients and provide feedback on information received. 
Contextual learning strategy, teaches not the transformation of knowledge from the teacher to students by memorizing a number of concepts that are independent of real life, but focuses on efforts to facilitate students to look for the ability to be able to live (life skills) from what they learn. One learning system according to Johnson [3] is based on CTL as follows: "The Contextual Teaching and Learning (CTL) system is an educational process that aims to help students see meaning in the academic material they are studying by connecting academic subjects with the context of their daily lives, that is, with the context of their personal, social, and cultural circumstances [3]. To achieve this aim, the system encompasses the following eight components: making meaningful connections, doing significant work, self-regulated learning, collaborating, critical and creative thinking, nurturing the individual, reaching high standards, using authentic assessment".

CTL communication strategy enables students to connect the contents of academic subjects with the context of everyday life. CTL expands students' personal contexts through experiences that stimulate the brain to establish real-world relationship [4]. Referring to the case study in the coastal area of Lero Tatari Village, 93\% of those who gave positive responses that the living environment influenced children's education. The level of community knowledge on children's education is very diverse, but basically, they are aware of the importance of education for the future.

There are four factors that influence the education of a fisherman's child: economic factors, environmental factors, parental education factors and motivational factors [5] The low quality of human resources especially in the coastal areas shows the low level of formal education. Four million Indonesian fishermen, $85 \%$ have elementary school education or are illiterate, $12 \%$ have a junior high school education, $2.97 \%$ have a senior high school education and $0.03 \%$ have a diploma education [6].

Learning communication system through learning strategies based on CTL students in coastal areas to introduce children directly to the natural surroundings so that children know the environment and the rich natural resources of the sea. Contextual learning focuses on the learning process of children who are able to process or construct information or knowledge to be meaningful. This learning approach assumes that the natural process of thinking in finding meaning is contextual. That is, there is a relationship between the learning process with the environment, knowledge, and experience they have (treasury of memory, experience, response). Students are motivated to do better learning activities, because it can help students to understand the meaning of teaching materials in the context of life so that the learning process is more fun. Contextual learning strategy is an educational process that aims to help students understand the meaning of the academic material they are learning by connecting their academic subjects with things that happen in everyday life both related to themselves, social society, and existing customs. around it [7].

Learning communication is a form of information exchange between educators and students that is done consciously, planned both inside and outside the room to improve students' abilities both changes in intellectual ability (cognitive), ability of interest or emotion (affective) and fine and gross motor skills (psychomotor) in students. Learning is a communication process, meaning that there is a process of delivering a message from someone (the source of the message) to someone or a group of people (recipient of the message), to achieve the learning objectives. 
Learning communication strategies based on CTL direct a learning message delivery strategy that emphasizes the linkages between learning material with the real world of student life, so students are able to connect and apply competencies in everyday life. [8]. His explanation according to Sanjaya [9] suggests that CTL is a learning concept that emphasizes the process of full student involvement to be able to find the material being studied and relate it to real life situations [9]. Learning communication strategy based on CTL is an educational process that aims to help students see the meaning / meaning of the message in the subject matter by connecting it with the context of daily life, namely with the context of the personal, social, and cultural environment.

Furthermore, the world of education according to Jourdan in the Instructional Communication book, states that education can only run through communication. In the world of education, communication is carried out namely instructional communication (learning). While the meaning of communication is more obtained from a communication process that serves to educate (to educate) to achieve maturity and independence. In the book "Instructional Communication" by Yusuf [10] written that educational communication as the main domain of instructional communication is communication that has penetrated or touched the world of education with all its aspects

Santoso Sastropoetro's research results in Pratikno [11] examine the effectiveness of communication, finding that communication is effective if the communicator and communicant both have the same understanding of a message, "the communication is in tune". [11]. Communication can run effectively, has the following conditions: first, creating a favorable communication atmosphere. Second, use language that is easily captured and understood. Third, the message delivered can arouse the attention or interest of the communicant. Fourth, the message can arouse the interests of the communicant that is not beneficial. Fifth, the message can foster an appreciation for the communicant.

Awareness of learning in education is still not optimal, especially children of fishermen on the coast in South Sulawesi including the province. Although the provision of access to free education has been programmed by the local government. However, the participation rate of basic education reaching more than $97 \%$ for both men and women has been socialized through communication media. Continuity of access to tertiary education has diminished. Decreased number of children continue their education to a higher level because of the pattern of noncommunicative learning systems.

The factor that needs to be maximized is the method of learning communication systems in educational institutions especially in the coastal regions of South Sulawesi. Especially in coastal or remote areas. Based on the results of direct visits to 11 regencies, problems were found that impeded teaching and learning activities. For example, the learning system in the classroom, the communication system between educators and educators is less intertwined. This has an impact on motivation/awareness of learning, as well as delays in disbursing free education funds both from provinces and districts/cities. [10]. An alternative solution is the application of a learning communication strategy based on CTL to increase the awareness of learning for children of fishermen on the coast in overcoming poverty in the future. The role of learning communication is important to increase the level of learning awareness towards fishermen children's higher education. 


\section{Research Method}

This research method uses a qualitative approach. Qualitative research is a humanistic research, which explains the naturalistic perspective and interpretive perspective of human experience. Garna in Creswell [12] argues that a qualitative approach is characterized by research objectives that seek to understand the symptoms that are impossible to measure accurately, research procedures that produce descriptive data in the form of speech or writing and the behavior of the people observed [12]. Qualitative research is expected to be able to produce an in-depth description of speech, writing, the behavior of individuals, groups, communities, and certain organizations in a context setting that is studied from a holistic, comprehensive and holistic perspective.

Sources of data in this study are primary data and secondary data. Primary data in this study are in the form of words and actions (verbal and nonverbal language). Primary data, data obtained directly from representative informants who know the issues under study. Furthermore, secondary data, namely data obtained from literature, documents and research results such as theories that are used as a reference.

Data collection techniques in this study, including techniques are first, observation is a space (place), actors, activities, objects, actions, events or events, time, and feelings. The reason researchers conduct observations is to present a realistic picture of the way they are delivered to answer questions, help understand the ways in which humans interact, and for evaluation that is measuring certain aspects and giving feedback on these measurements. Researchers make observations directly at the study site to see and observe the activities of a series of actions taken. Second, in-depth interviews are the process of obtaining information used by researchers to obtain oral information through direct dialogue with respondents in order to obtain accurate data or in other words use question and answer face to face between the interviewer and the informant or the person being interviewed, with or without use interview guides.

The location of this research is in the area of South Sulawesi province. An area of land located along the coastline whose main occupation is fishing. MDIT Paotere elementary school teacher in the coastal area of Makassar City. This is based on the mapping of the area of having teachers living around the coast and the majority of family heads working as fishermen and having children attending school in the coastal area.

Data analysis is the process of processing research results, starting to compile, classify, examine, and interpret data in patterns and relationships between concepts and formulate them in the relationships between elements. Data analysis techniques in descriptive qualitative research, which means data relating to collecting data in the form of words, images, and not numbers (statistics). Describe in the form of a broader and detailed explanation so that the qualitative phenomena can be understood.

\section{Result And Discussion}

Learning communication strategy based on CTL is a learning concept that emphasizes the relationship between learning material and the world of student life. The goal is that students are able to connect and apply competencies in everyday life. CTL based strategies, namely learning that emphasizes the process of full student involvement to be able to find educational learning material that is learned and relate it to real life situations. Teacher learning 
communication strategies in the classroom, especially students on the coast include readiness and motivation, the use of assistive communication media, children's participation, repetition, and feedback, in accordance with the practice of implication of the effectiveness of learning communication.

This CTL learning strategy is to achieve skills in the context of real life or learning in the natural environment. Learning communication strategies are carried out through the opening stages, conveying the message of learning objectives and motivating children, the stages of teaching; delivering informative material and guiding children in learning and working activities. Closing phase; material evaluation and learning award. The impact of the learning communication process can apply learning outcomes in their daily lives. This strategy is expected to stimulate the children of fishermen to be motivated to improve higher levels of education. The recapitulation of research observations later, summarized in the following table 1:

Table 1. Teaching-Based Communication Strategy Research Results Contextual Teaching and Learning (CTL)

\begin{tabular}{|c|c|}
\hline Learning Communication Strategy & Teacher's behavior \\
\hline Stage I: Readiness and motivation & $\begin{array}{l}\text { The teacher conveys the learning objectives } \\
\text { to be achieved in these lessons and } \\
\text { motivates student learning, learning goals } \\
\text { and ideals. }\end{array}$ \\
\hline $\begin{array}{l}\text { Stage II: The use of auxiliary } \\
\text { communication media }\end{array}$ & $\begin{array}{l}\text { The teacher presents information to } \\
\text { students by demonstration or through aids } \\
\text { and helps share experiences in their } \\
\text { environment }\end{array}$ \\
\hline $\begin{array}{l}\text { Stage III: Active participation of } \\
\text { children }\end{array}$ & $\begin{array}{l}\text { The teacher encourages students to gather } \\
\text { appropriate information, carry out } \\
\text { experiments to get explanations and } \\
\text { problem solving based on experience }\end{array}$ \\
\hline Stage IV: Repetition & $\begin{array}{l}\text { The teacher helps students to reflect or } \\
\text { evaluate and contextualize the processes } \\
\text { they use in the social environment. }\end{array}$ \\
\hline Stage V: Feedback & $\begin{array}{l}\text { The teacher evaluates the learning } \\
\text { outcomes of the material that has been } \\
\text { learned or each group presents } \\
\text { The teacher looks for ways to appreciate } \\
\text { and the results of individual and group } \\
\text { learning in everyday life }\end{array}$ \\
\hline
\end{tabular}

CTL learning system to increase coastal children's learning awareness. The aim is to motivate students to understand the meaning of subject matter, especially social studies and natural sciences they learn. Learning communication strategies in increasing the learning awareness of fishermen children include communication in class in the form of learning readiness, learning motivation and repetition of subject matter are learning principles providing student awareness of learning that can influence learning outcomes. 
Increased learning awareness based on CTL refers to their characteristics in using learning systems that include, learning systems: first, connecting is learning in the context of a real-life experience or beginning before the knowledge is obtained by students. Second, trying (experiencing) can also they do not have direct experience with regard to the concept. Third, applying is learning by applying the concept. In fact, students apply concepts when they relate to hands-on problem solving activities and projects. Fourth, cooperating (collaborating) learning in the context of sharing, responding, and communicating with other students is the main instructional strategy in contextual teaching. Fifth, the process of transfer of knowledge (transferring) is a teaching strategy that we define as the use of knowledge in a new context or a new situation something that has not been resolved / resolved in the classroom.

Learning awareness of coastal fishermen children based on CTL is obtained from collaboration with others. Learning awareness can be obtained by sharing among friends, groups, and between those who know to those who don't know, both inside and outside the classroom. This component occurs when there is a two-way communication process. Because learning that is designed in group discussions with heterogeneous members and varying numbers strongly supports this component.

In CTL the teacher acts as an ongoing and continuous facilitator, which is to help students find meaning (knowledge). Students have response potentiality. The teacher is tasked with empowering the potential of students so that students are trained to grasp the meaning of the material being taught. The results of the tendency of learning strategies based on CTL in increasing awareness of coastal learning students as follows:

Table 2. Contextual Teaching and Learning (CTL) Based Student Learning In Increasing Learning Awareness

\begin{tabular}{|c|c|c|c|c|c|}
\hline \multirow{2}{*}{$\begin{array}{c}\text { Learning } \\
\text { Communication } \\
\text { Strategy }\end{array}$} & \multicolumn{5}{|c|}{ Contextual Teaching and Learning (CTL) } \\
\hline & Relating & Experiencing & Applying & Cooperating & Transferring \\
\hline $\begin{array}{l}\text { Readiness and } \\
\text { motivation }\end{array}$ & Low & Moderate & Low & Low & Moderate \\
\hline $\begin{array}{l}\text { The use of } \\
\text { auxiliary } \\
\text { communication } \\
\text { media }\end{array}$ & Moderate & Low & Low & Moderate & Low \\
\hline $\begin{array}{l}\text { Active } \\
\text { participation of } \\
\text { children }\end{array}$ & High & Moderate & Moderate & High & Moderate \\
\hline Repetition & Moderate & Moderate & Low & Moderate & Low \\
\hline Feedback & Moderate & Low & Low & Moderate & Low \\
\hline
\end{tabular}

CTL learning presents the real world in the classroom to connect knowledge that is applied in real life. CTL enables a learning process that is calm and enjoyable, because learning is done naturally, thus allowing participants to practice directly the material learned. The communication strategies of teacher readiness and motivation-based learning CTL in increasing student learning awareness in coastal areas show a low tendency in relating, applying, and cooperating. However, for experiencing and transferring moderate category learning material. Teacher learning communication in terms of the use of communication 
media aids a low tendency to experience, applying, and transferring, but for relating and cooperating to moderate categories, active participation of fishing children for relating, and cooperating high and moderate for experiencing, applying and transferring.

Repetitive learning strategies and feedback in increasing learning awareness based on CTL moderate tendencies, respectively for relating, cooperating and experiencing specifically for repetition. CTL tends to be Low tendency towards applying and transferring, encouraging participants to understand the nature, meaning, and benefits of learning, thus enabling them to be diligent, and motivated in learning. Contextual learning and teaching involve students in important activities that help them connect academic learning with the real-life context they face.

\section{Conclusion}

Learning communication strategy based on CTL in increasing the awareness of learning of children/students in coastal areas shows a low tendency in regard to, applying, and cooperating. However, for experiencing and transferring moderate category learning materials. In terms of the use of communication media aids a low tendency to experience, applying, and transferring, but for relating and cooperating to moderate categories. Active participation of fishing children for relating, and cooperating high and moderate for experiencing, applying and transferring. Repetitive learning strategies and feedback in increasing learning awareness based on CTL moderate tendencies, respectively for relating, cooperating and experiencing specifically for repetition. Furthermore, the low category on applying and transferring.

Acknowledgments. The authors thank to the Featured Basic Research Universities (PDUPT Decentralization Unhas 2019). Jessica and Erwinda as an enumerator who has helped primary data collection in Makassar City, South Sulawesi. Family of research informants who have provided representative data.

\section{References}

[1] Warlianti.: Hubungan Antara Ctl (Contextual Teaching And Learning) Berbasis Multi Intelegensi Dengan Kemampuan Kognitif Siswa Mata Pelajaran IPS Terpadu Smp Negeri 7 Parepare. Tesis UNM tidak diterbitkan.," Universitas Negeri Makassar, Makassar (2014)

[2] A. Masri.: Pendidikan Anak Nelayan Pesisir Pantai Donggala (The Education For Coastal Fishermen Children In Donggala). Asian Journal of Environment, History and Heritage. pp.223-227 (2017)

[3] Johnson. E. B.: Contextual Teaching and Learning, Bandung MLC (2007)

[4] Rusman.: Model-Model Pembelajaran, Mengembangkan Profesionalisme Guru, Jakarta. Rajawali Pers (2011)

[5] Mutriana.:Pendidikan Anak Dalam Perspektif Masyarakat Nelayan Di Desa Lero Tatari Kecamatan Sindue Kabupaten Donggala Mutriani. E- Journal Geo-Tadulako UNTAD (2016)

[6] N. Sriyanti, I. Muflikhati a A. Fatchiya.: Persepsi Nelayan tentang Pendidikan Formal Di Kecamatan Rembang, Kabupaten Rembang Provinsi Jawa Tengah,Buletin Ekonomi Perikanan.pp. 40-49 (2006)

[7] Johnson.E.B: Contextual Teaching and Learning What It is and Why It's Here to Stay, California: Corwin Press Inc (2002) 
[8] Mulyasa.E: Menjadi Guru Profesional Menciptakan Pembelajaran Kreatif dan Menyenangkan, Bandung: Remaja Rosda Karya. (2005)

[9] Sanjaya.W.: Strategi Pembelajaran Berorientasi Standar Proses Pendidikan, Jakarta. PT Kencana (2007)

[10] Fatimah.J.M.: Komunikasi Keluarga Meningkatkan Akses Pendidikan Bagi Kesetaraan Anak Perempuan dalam Lingkaran Kemiskinan. Laporan Hasil Penelitian. Kemenristekdikti, Indonesia (2014)

[11] Pratikno.: Remadja Karya, Berbagai Aspek Ilmu Komunikasi (2015)

[12] Creswell. J. W.: Research Design Qualitative and Quantitative Approaches., California: Thousand Oaks, Sage Publications Inc (2004) 